\title{
Mengembangkan Kemampuan Koneksi Matematis Melalui Buku Ajar Elektronik Interaktif (BAEI) yang Terintegrasi Nilai-Nilai Keislaman
}

\author{
Nanang Supriadi \\ IAIN Raden Intan : nanangsupriadi@gmail.com
}

Submitted : 17-03-2015, Revised : 14-04-2015, Accepted : 16-06-2015

\begin{abstract}
Learning by using electronic textbooks should have more value than regular print books that are widely circulated. More value is there because the use of BAE must use a tool in the form of a computer (PC), e-book reader, tablet, or smartphone to open it. With the tools used, it is fitting that BAE is capable of displaying interactive simulations with added features in the form of video, animation, sound or image. This textbook is known as Interactive Electronic Textbook (BAEI). Islamic madrasahs and universities are now beginning to develop the integration of science sciences into Islamic values. The integration of Islamic values in mathematics textbooks can at least be reflected in examples of problems, exercises and test questions that address issues that occur in the perspective of Islam without changing the standard of competence contained in the prescribed curriculum. The visualization presented in the BAEI can be Driven and modified in shape and size, giving students the opportunity to explore and observe easily so that the ability of mathematical connections can increase. This is evident from the results of research that has been done. This research is a research experiments pretest-postes design with the aim of answering the problem whether there is an increase in mathematical connection ability of students by using interactive electronic teaching materials that integrate Islamic values. The subjects of the study were 32 students of class XI, the instruments used in this study were tested and consisted of two sets of tests for mathematical connection ability. The statistical hypothesis in this study was tested using $t$ test with 5\% significance level. The result of statistical test shows that there is improvement of mathematical connection ability of students by using interactive electronic teaching materials integrated with Islamic values.
\end{abstract}

Keywords: Interactive Electronic Teaching Materials, Integration of Islamic Values, Mathematical Connection Ability.

\begin{abstract}
Abstrak
Pembelajaran dengan menggunakan buku ajar elektroniksemestinya memiliki nilai lebih dibandingkan dengan buku cetak biasa yang banyak beredar. Nilai lebih tersebut ada karena pemakaian BAE harus menggunakan alat bantu berupa komputer (PC), e-book reader, tablet, maupun smartphone untuk membukanya. Dengan alat bantu yang digunakan, sepatutnya BAE mampu menampilkan simulasi-simulasi yang interaktif dengan ditambahkan fitur-fitur berupa video, animasi, suara maupun gambar. Buku ajar seperti ini dikenal dengan istilah Buku Ajar Elektronik Interaktif (BAEI). Madrasah dan Perguruan Tinggi Islam dewasa ini mulai mengembangkan pengintegrasian ilmu-ilmu sains ke dalam nilai-nilai keislaman. Pengintegrasian nilai-nilai keislaman dalam buku ajar matematika setidaknya dapat
\end{abstract}


tergambar dalam contoh soal, soal latihan dan soal ujian yang mengangkat masalah-masalah yang terjadi dalam perpekstif islam tanpa mengubah standar kompetensi yang terkandung dalam kurikulum yang telah ditetapkan.Visualisasi yang ditampilkan dalam BAEI yang dapat digerakkan dan diubah bentuk serta ukurannya, memberi kesempatan kepada siswa untuk melakukan eksplorasi dan observasi dengan mudah sehingga kemampuan koneksi matematis dapat meningkat. Hal ini terbukti dari hasil penelitian yang telah dilakukan.Penelitian ini merupakan penelitiankuasi eksperimen berdisain pretes-postes dengan tujuan menjawab permasalahan apakah terdapat peningkatan kemampuan koneksi matematis siswa dengan menggunakan bahan ajar elektronik interaktif yang terintegrasi nilai-nilai keislaman. Subyek penelitian sebanyak 32 siswa kelas XI, instrumen yang digunakan dalam penelitian ini berbentuk tes dan terdiri dari dua perangkat tes untuk kemampuan koneksi matematis. Hipotesis statistik dalam penelitian ini diuji menggunakan uji $t$ dengan taraf signifikansi 5\%. Hasil uji statistik menunjukkan bahwa terdapat peningkatan kemampuan koneksi matematis siswa dengan menggunakan bahan ajar elektronik interaktif yang terintegrasi nilai-nilai keislaman.

Kata Kunci: Bahan Ajar Elektronik Interaktif, Integrasi Nilai-nilai Keislaman, Kemampuan Koneksi Matematis.

\section{PENDAHULUAN}

Matematika sebagai salah satu mata pelajaran wajib yang ada untuk setiap jenjang pendidikan formal dan mata pelajaran yang diujikan dalam ujian nasional (UN), haruslah memiliki kelengkapan pembelajaran yang memadai agar kegiatan belajar mengajar di kelas berjalan sesuai dengan kompetensi dasar yang diharapkan. Kelengkapan yang dimaksud antara lain guru, buku ajar, sarana dan prasarana. Pada prakteknya justru unsur-unsur tersebut sering kali bermasalah. Salah satu unsur yang paling sering bermasalah adalah buku ajar.

Buku ajar yang kini banyak digunakan di berbagai sekolah/madrasyah dan bahkan perguruan tinggi di Indonesia adalah buku ajar elektronik (BAE). BAE adalah buku teks pelajaran yang hak ciptanya telah dibeli atau memang disediakan gratis oleh penerbit dan disajikan dalam bentuk e-book yang berformat Protable Document Format (PDF). Pengguna dapat mengunduh (download) dan mencetak file BAE serta menggandakan, bahkan memperdagangkan buku ini. Akan tetapi, layaknya seperti buku-buku ajar yang lain, buku ini masih memiliki kelemahan-kelemahan yang patut disempunakan. Nuryadin (2004) mengatakan bahwa kelemahan menonjol buku-buku teks adalah penggunaan bahasa dan ilustrasi yang tidak komunikatif dan interaktif sehingga tidak berhasil menyampaikan pesan inti buku. Dengan kondisi buku seperti ini, sangat diragukan ketika buku ini digunakan kita berharap akan tercapainya kompetensi siswa seperti yang tertera dalam kurikulum tahun 2013.

Buku Ajar Elektronik yang dikemas dalam bentuk e-book ini semestinya memiliki nilai lebih dibandingkan dengan buku cetak biasa yang banyak beredar. Nilai lebih tersebut seharusnya ada karena pemakaian BAE harus menggunakan alat bantu berupa komputer (PC), e-book reader, tablet, maupun smartphone untuk membukanya. Oleh karenanya, dengan memanfaatkan kemampuan alat bantu yang digunakan, sepatutnya BAE mampu 
menampilkan simulasi-simulasi yang interaktif dengan ditambahkan fitur-fitur berupa video, animasi, suara maupun gambar. Simulasi-simulasi tersebut akan membantu siswa dalam memvisualisasikan materi yang bersifat abstrak dari matematika. Buku ajar seperti ini dikenal dengan istilah Buku Ajar Elektronik Interaktif (BAEI).

Integrasi nilai-nilai keislaman dalam pelajaran matematika di Madrasah dan Perguruan Tinggi Islam dewasa ini mulai dikembangkan, pengintegrasian inilah yang dapat membedakan pendidikan di Sekolah dan Perguruan Tinggi Umum dengan Madrasah dan Perguruan Tinggi Islam yang kental dengan nilai-nilai keislaman yang diterapkan. Integrasi nilai-nilai keislaman yang dimaksud di sini adalah berkaitan dengan usaha memadukan keilmuan matematika secara umum dengan Islam tanpa harus menghilangkan keunikankeunikan antara dua keilmuan tersebut. Pengintegrasian nilai-nilai keislaman dalam buku ajar matematika setidaknya dapat tergambar dalam contoh soal, soal latihan dan soal ujian yang mengangkat masalah-masalah yang terjadi dalam perpekstif islam tanpa mengubah standar kompetensi yang terkandung dalam kurikulum yang telah ditetapkan.

Penggunaan BAEI yang terintegrasi dengan nilai-nilai kesilaman dapat merangsang siswa untuk dapat menghubungkan topik-topik matematika yang disajikan dengan peristiwa, kejadian, masalah yang terjadi dalam kehidupan sehari-hari khususnya dalam penerapan praktek pengamalan ibadah yang dijalankan. Kemampuan siswa yang dapat menghubungkan ide matematis dengan konsep, keterampilan, peristiwa dan situasi lain dalam kehidupan sehari-hari dikenal dengan istilah kemampuan koneksi matematis. Koneksi dalam matematika terjadi dalam beberapa bentukRiedesel (1996), yaitu: (1) koneksi antar topik matematis; (2) koneksi antar representasi; (3) koneksi antar keterampilan matematis; (4) koneksi matematis dengan mata pelajaran lain.

Pemanfaatan teknologi yang ada dalam BAEI juga memungkinkan pembelajaran matematika berlangsung dengan efektif. Hal ini dikarenakan dengan memanfaatkan teknologi informasi siswa dapat bereksplorasi pada materi yang disajikan, berlatih menggunakan pikirannya secara logis, analitis, sistematis, kritis dan kreatif serta memiliki kemampuan bekerjasama dalam menghadapi berbagai masalah serta mampu memanfaatkan informasi yang diterimanya. Lebih dari itu teknologi dapat menampilkan visualisasi dari materi ajar yang diberikan secara cepat dan akurat.

Visualisasi yang ditampilkan secara menarik, dapat digerakkan dan diubah bentuk serta ukurannya, memberi kesempatan kepada siswa untuk melakukan eksplorasi dan observasi dengan mudah. Eksplorasi sangat diperlukan ketika siswa berusaha memahami suatu konsep atau membangun pengetahuan. Conway (2006) menyebutkan peran teknologi dalam pembelajaran matematika sebagai berikut: (1) Mengembangkan pengetahuan multirepresentasi; (2) Meningkatkan pemahaman konseptual; (3) Mengakomodasi gaya belajar yang berbeda. Eksplorasi dan observasi dengan bantuan BAEI dalam pembelajaran matematika sangat penting dilakukan guna mengembangkan kemampuan koneksi matematis siswa.

Pengembangan kemampuan berpikir, khususnya yang mengarah pada kemampuan koneksi matematis, perlu mendapat perhatian serius karena sejumlah hasil studi seperti Peterson (1988) menunjukkan bahwa pembelajaran matematika pada umumnya masih berfokus pada pengembangan kemampuan berpikir tahap rendah yang bersifat prosedural.

Lebih lanjut penelitian Henningsen dan Stein (1997) menjelaskan bahwa sebagian besar pembelajaran matematika belum berfokus pada pengembangan koneksi matematis 
siswa. Secara umum pembelajaran matematika masih terdiri atas rangkaian kegiatan berikut: awal pembelajaran dimulai dengan sajian masalah oleh guru, selanjutnya dilakukan demonstrasi penyelesaian masalah tersebut, dan terakhir guru meminta siswa untuk melakukan latihan penyelesaian soal.

Penelitian Peterson juga menunjukkan bahwa pembelajaran yang lebih menekankan pada aktivitas koneksi matematis dan pemecahan masalah matematis sangat erat kaitannya dengan capaian prestasi siswa yang tinggi. Sebagai contoh, pembelajaran matematika di Jepang dan Korea yang lebih menekankan pada kedua kemampuan tersebut telah mampu menghasilkan siswa berprestasi tinggi pada pelajaran matematika dala $\mathrm{m}$ tes yang dilakukan oleh Trends in International Mathematics and Science Study (TIMSS).

Hasil penelitian Mullis (2000)memperlihatkan bukti lebih jelas bahwa soal-soal matematika tidak rutin yang memerlukan kemampuan berpikir tingkat tinggi pada umumnya tidak berhasil dijawab dengan benar oleh sampel siswa Indonesia. Untuk penyelesaian soalsoal seperti itu, prestasi siswa Indonesia berada jauh di bawah rata-rata internasional.

Sutiarso (2000) mengemukakan juga kenyataan di lapangan justru menunjukkan siswa pasif dalam merespon pembelajaran. Siswa cenderung hanya menerima transfer pengetahuan dari guru. Demikian pula guru pada saat kegiatan pembelajaran hanya sekadar menyampaikan informasi pengetahuan tanpa melibatkan siswa dalam proses yang aktif dan generatif.Padahal menurut Fisher (1995) jika siswa diharapkan menjadi siswa yang mandiri, mereka perlu aktif dan dihadapkan pada kesempatan-kesempatan yang memungkinkan mereka berpikir, mengamati dan mengikuti pikiran orang lain.

Sebagai upaya untuk meningkatkan kemampuan koneksi matematis siswa, maka dalam penelitian ini penulis akan menerapkan penggunaan BAEI terintegrasi nilai kesilaman yang telah dihasilkan pada penelitian sebelumnyaguna mengembangkan kemampuan koneksi matematis siswa menjadi lebih baik.

Dalam belajar matematika, siswa melaksanakan aktivitas-aktivitas belajar seperti menerima, mengolah atau mengungkapkan gagasan-gagasan maupun ide-ide matematika. Untuk menghubungkan berbagai macam gagasan-gagasan atau ide-ide matematis yang diterima oleh siswa, diperlukan kemampuan koneksi matematis (mathematical connection). Koneksi matematis merupakan salah satu kemampuan standar yang sudah ditetapkan oleh NCTM serta sudah diadopsi dan digunakan dalam pembelajaran matematika oleh banyak negara. Dengan melihat banyaknya konsep, gagasan atau ide dalam matematika, maka kemampuan koneksi matematis menjadi penting untuk dikembangkan agar gagasan-gagasan atau ide-ide matematika tersebut tidak dipahami saling terpisah oleh siswa.

Dalam mengembangkan koneksi matematis, Harnisch (2003) mengemukakan 3 macam koneksi yang harus dikembangkan, yaitu: (1) data connection, yaitu ide-ide matematika dikoneksikan dengan ide dalam science, misalkan "log" dalam math dihubungkan dengan $\mathrm{pH}$ dalam kimia. (2) language connection, yaitu bahasa yang umum digunakan dalam matematika dikaitkan dengan bahasa yang digunakan dalam sains, misalnya penggunaan satuan panjang $\mathrm{cm}, \mathrm{cm} 2$, dan lain-lain. (3) life connection, yaitu matematika dan science dihubungkan dengan kehidupan sehari-hari. Dalam penelitiannya, Harnisch (2003) juga menemukan bahwa siswa bisa mendapatkan gambaran tentang konsep dan ide-ide yang besar mengenai hubungan-hubungan antar matematika dan sains, serta siswa mendapatkan pengalaman yang lebih banyak. 
Tentang pentingnya mengembangkan koneksi dalam matematika, Mousley (2004) menyatakan bahwa membangun koneksi matematis merupakan aktifitas sangat penting yang harus dilakukan oleh guru dan siswa dalam pembelajaran matematika agar bisa terbentuk pemahaman matematis siswa. Selanjutnya, Mousley menyatakan bahwa terdapat tiga macam koneksi matematis yang perlu dikembangkan yaitu: (a) koneksi antara pengetahuan matematika baru dengan pengetahuan matematika yang sudah ada sebelumnya; (b) koneksi antar konsep-konsep matematika, dan (c) koneksi antara matematika dengan kehidupan sehari-hari.

Geller (2008) menyatakan bahwa pembelajaran matematika dengan mengembangkan koneksi-koneksi dalam matematika memberikan hasil yang lebih baik dibandingkan dengan pembelajaran biasa pada siswa dengan kemampuan rendah (lowperforming students) kelas 8 di Pacific Northwest, Amerika Serikat. Penelitian Geller ini juga menunjukkan kaitan yang sangat erat antara pengembangan koneksi matematis dan pemahaman matematis dalam pembelajaran matematika.

Businkas (2005) dalam penelitiannya menyatakan bahwa para guru pada pembelajaran matematika dalam mengembangkan koneksi matematis menekankan pada hubungan antara matematika dengan dunia nyata. Para guru melihat bahwa hubungan yang dikembangkan tersebut sangat bermanfaat untuk membantu meningkatkan pemahaman dan motivasi belajar mereka.

Mousley (2004) menerangkan tentang hal-hal yang harus ditekankan pada pembelajaran untuk mengembangkan kemampuan koneksi matematika, yaitu: (a) meluaskan cakupan dari isi matematika yang dipelajari untuk memberi anak-anak suatu pengertian yang luas dari matematika dan aplikasi-aplikasinya, (b) menekankan koneksi antar ide-ide matematika, (c) meng-eksplorasi matematika dengan memperkaya situasi kehidupan nyata, (d) memberikan arahan pada siswa untuk menemukan solusi yang lebih dari satu dan menemukan koneksi antar solusi-solusi tersebut, (e) membuat beragam representasi terhadap suatu ide matematika.

Sumarmo (1987) mengungkapkan bahwa yang tergolong kemampuan koneksi matematik adalah: mencari hubungan berbagai representasi konsep dan prosedur; memahami hubungan antar topik matematika; menerapkan matematika dalam bidang lain atau dalam kehidupan sehari-hari; memahami representasi ekuivalen suatu konsep; mencari hubungan satu prosedur dengan prosedur lain dalam representasi yang ekuivalen; dan menerapkan hubungan antar topik matematika dan antara topik matematika dengan topik di luar matematika.

Dalam NCTM (2000) dinyatakan bahwa standar koneksi matematis adalah penekanan pembelajaran matematika pada kemampuan siswa yang meliputi:

a. mengenali dan memanfaatkan hubungan-hubungan antar gagasan-gagasan matematis;

b. memahami bagaimana gagasan-gagasan matematis saling berhubungan dan saling mendasari satu sama lain untuk menghasilkan suatu keutuhan yang saling koheren;

c. mengenali dan menerapkan matematika di dalam konteks-konteks di luar matematika.

\section{METODE PENELITIAN}


Penelitian ini adalah penelitian eksperimen, dengan desain pretes postes yang menggunakan bahan ajar elektronik interaktif terintegrasi nilai-nilai keislaman. Penelitian ini menggunakan satu kelompok siswa yang diteliti dalam hal kemampuan koneksi matematis. Sebelum diberikan perlakuan pembelajaran, kelompok tersebut diberikan tes awal (pretes) mengenai kemampuan koneksi matematis siswa. Setelah diberi perlakuan, kemudian diberi tes akhir (postes) untuk mengetahui peningkatan kemampuan koneksi matematis siswa.

Instrumen penelitian ini berbentuk tes, tes kemampuan koneksi matematis merupakan tes kemampuan berpikir yang berfungsi untuk mengungkap kemampuan koneksi matematis yang dimiliki siswa dalam berbagai permasalahan. Tes kemampuan koneksi matematis, berbentuk tes uraian yang terdiri dari 7 soal. Data yang diperoleh dari skor hasil tes kemampuan koneksi matematis dibandingkan skor total dari tiap siswa hasil postes. Tingkat signifikansi peningkatan kemampuan koneksi matematis setelah siswa menggunakan bahan ajar elektronik interaktif yang terintegrasi nilai-nilai keislaman diuji dengan menggunakan statistik uji $t$.

\section{HASIL PENELITIAN DAN PEMBAHASAN}

Pencapaian skor pretest dan posttest kemampuan koneksi matematis siswa di atas dapat menggambarkan keadaan data peningkatan kemampuan koneksi matematis melalui perhitungan normalized gain(n-gain). Deskripsi skor peningkatankemampuan koneksi matematis merupakan gambaran peningkatan kemampuan koneksi matematis siswa setelah melaksanakan tes awal dan tes akhir. Skor yang ditampilkan adalah rerata, simpangan baku, dan jumlah siswa, data ini didapat dari hasil tes kemampuan koneksi matematis sebanyak 6 soal. Gambar 1. menyajikan deskripsi data peningkatan kemampuan koneksi matematis siswa.

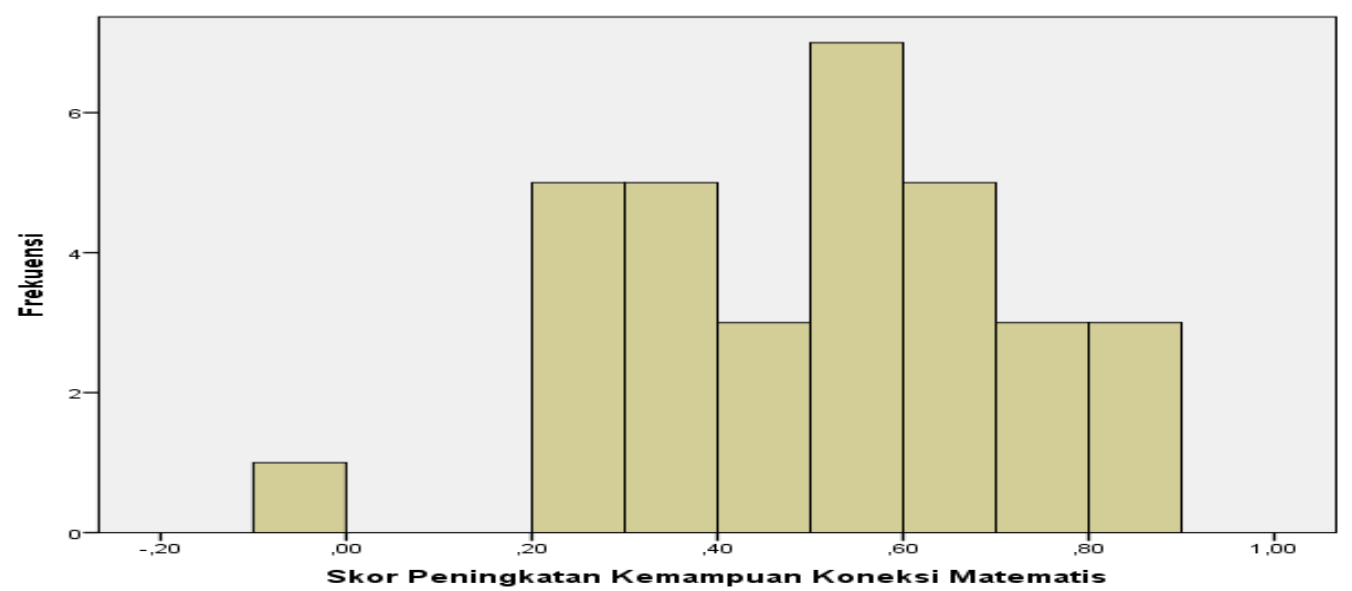

Gambar 1. Skor Hasil Tes Akhir Kemampuan Koneksi Matematis

Pada Gambar 1 terlihat peningkatankemampuan koneksi matematis siswa secara keseluruhan, siswa yang memperoleh peningkatan kemampuan dengan kategori tinggi $(>70)$ sebesar $19 \%$, siswa yang memperoleh peningkatan kemampuan dengan kategori sedang $(0,3$ $<x<70$ ) sebesar $63 \%$, sedangkan siswa yang memperoleh peningkatan kemampuan dengan kategori rendah $(<30)$ sebesar $18 \%$. Hal ini berarti bahwa perolehan peningkatan 
kemampuan koneksi matematis siswa sebagian besar berada pada kategori sedang. Hasil deskripsi Gambar 1 di atas diperkuat oleh hasil perhitungan output SPSS pada Table 1 berikut:

Tabel 1. Statistik Deskriptif Peningkatan Kemampuan Koneksi Matematis

\begin{tabular}{|c|c|c|c|c|c|c|}
\hline & $\mathrm{N}$ & Min & Max & Mean & Std. Dev & Variance \\
\hline Posttest & 32 & $-0,02$ & 0,89 & 0,5025 & 0,21059 & 0,044348 \\
Valid N & 32 & & & & & \\
\hline
\end{tabular}

Tabel 1 di atas memperlihatkan bahwa dari 32 siswa yang mendapat pembelajaran menggunakan bahan ajar elektronik interaktif yang terintegrasi nilai keislaman terdapat seorang siswa yang skor peningkatannya bernilai negative, hal ini berarti siswa tersebut justru memiliki nilai tes akhir yang lebih kecil dari skor tes awalnya. Secara rata-rata skor peningkatan kemampuan koneksi matematis berada pada kategori sedang.

Hasil statistik deskriptif ini memunjukkan bahwa kemampuan koneksi matematis siswa mengalami peningkatan hasil lebih dari 50\% siswa pada kategori sedang. Untuk memperkuat temuan ini diperlukan uji lanjut menggunakan statistikinferensial.

Untuk melakukan analisis inferensial perlu dilakukan terlebih dahulu uji normalitas, untuk menentukan uji statistik yang digunakan apakah parametrik atau non parametrik. Setelah itu dilakukan uji homogenitas untuk mengetahui kelayakan statistik inferensial pada data dua kelompok skor kemampuan koneksi matematis. Uji normalitas dilakukan dengan menggunakan uji Kolmogorov-Smirnov. Rangkuman hasil perhitungan uji normalitas disajikan pada Tabel 2.

Tabel 2. Uji Normalitas Skor normalized gain Kemampuan Koneksi Matematis Siswa

\begin{tabular}{|c|c|c|c|}
\hline & \multicolumn{3}{|c|}{ Kolmogorov-Smirnov } \\
\cline { 2 - 4 } & Statistic & Df & Sig. \\
\hline Gain & $\mathbf{0 , 0 7 9}$ & $\mathbf{3 2}$ & $\mathbf{0 , 2 0 0}$ \\
\hline
\end{tabular}

Dari Tabel 2 tampak bahwa skor uji Kolmogorov-Smirnov normalized gainkemampuan koneksi matematis menghasilkan nilai sig. 0,200 yang lebih besar dari nilai $\alpha$ yang ditentukan sebesar 0,05 . Hal ini berarti bahwa hipotesis nol kita tolak dan dapat disimpulkan skor normalized gainkemampuan koneksi matematis berdistribusi normal. Perhitungan selanjutnya adalah menguji homogenitas tiap kelompok skor kemampuan koneksi matematis, uji homogenitas dilakukan dengan uji Levene. Rangkuman hasil perhitungan disajikan pada Tabel 3.

Tabel 3. Uji Homogenitas Normalized Gain Kemampuan Koneksi Matematis Siswa

\begin{tabular}{|l|l|r|c|}
\hline \multicolumn{2}{|l|}{} & Levene Statistic & \multicolumn{1}{c|}{ Sig. } \\
\hline Normalized Gain & Based of Mean & 2,383 & 0,128 \\
\hline
\end{tabular}

$\mathrm{H}_{0}$ : Kelompok memiliki variansnya Sama

Tabel 3 menunjukkan bahwa nilai Sig. pada uji Levene pada kedua kelompok lebih besar dari $\alpha=0,05$, sehingga dapat disimpulkan bahwa skor peningkaatan koneksi matematis siswa berasal dari populasi yang homogen.Setelah diketahui bahwa kelompok sampel 
penelitian berdistribusi normal dan homogen, selanjutnya dilakukan uji perbedaan rerata skor tes awal dan tes akhir kemampuan koneksi matematis siswa.

Untuk menguji perbedaan rerata skor tes awaldan tes akhir kemampuan koneksi matematis siswa digunakan uji t. Rangkuman hasil perhitungan uji perbedaan rerata disajikan pada Tabel 4.

Tabel 4. Uji Perbedaaan Rerarta Kemampuan Koneksi Matematis Siswa

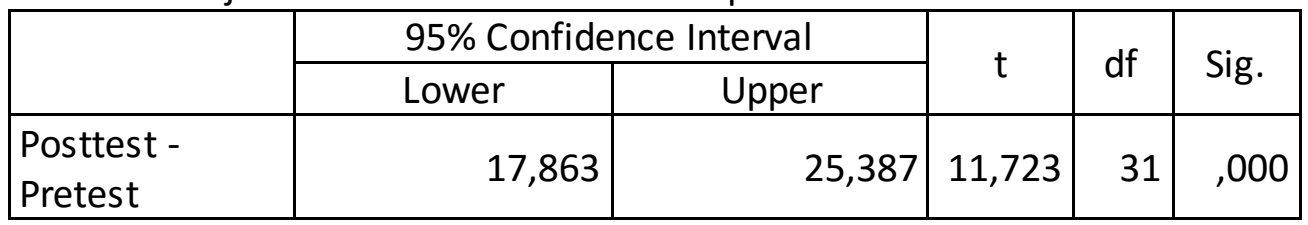

Pada Tabel 4 tampak bahwa uji perbedaan rerata kemampuan koneksi matematis siswa memperoleh nilai thitung $=11,723$ dengan Sig. $=0,000$ yang lebih kecil dari $\alpha=0,05$ sehingga $\mathrm{H}_{0}$ ditolak. Artinya terdapat perbedaan pencapaian rerata skor kemampuan koneksi matematis siswa secara signifikan pada siswa sebelum melaksanakan pembelajaran menggunakan bahan ajar elektronik interaktif yang terintegrasi nilai-nilai keislaman dan sesudah menggunakan bahan ajar elektronik interaktif yang terintegrasi nilai-nilai keislaman. Kesimpulannya penggunaan bahan ajar elektronik interaktif yang terintegrasi nilai-nilai keislamanmampu meningkatkan kemampuan koneksi matematis siswa secara signifikan.

Penelitian ini menghasilkan beberapa temuan tentang peningkatan kemampuan koneksi matematis siswa melalui penerapan pembelajaran menggunakan bahan ajar elektronik interaktif yang terintegrasi nilai-nilai keislaman.Temuan ini kemudian dianalisis berdasarkan faktor pembelajaran dan peningkatan kemampuan koneksi matematis siswa. Berikut akan dibahas temuan dari penelitian ini sesuai dengan faktor-faktor tersebut di atas:

Berdasarkan hasil penelitian dapat dikemukakan bahwa siswa yang belajar matematika menggunakan bahan ajar elektronik interaktif yang terintegrasi nilai-nilai keislamanmengalami peningkatan komunikasi matematis sebesar $64 \%$, hal tersebut menunjukkan bahwa setelah mendapat pembelajaran dengan menggunakan bahan ajar elektronik interaktif yang terintegrasi nilai-nilai keislaman meningkat jauh lebih tinggi dibandingkan sebelum menggunakan bahan ajar elektronik interaktif yang terintegrasi nilainilai keislaman.

Terjadinya peningkatan kemampuan koneksi matematis melalui pembelajaran menggunakan bahan ajar berbasis teknologi informasi disebabkan oleh perbedaan mendasar yang terjadi selama proses pembelajaran, pada kelompok siswa yang mendapatkan pembelajaran tanpa penggunaan teknologi informasi, siswa memperoleh pengetahuan tentang fakta, konsep dan prosedur hanya bersumber dari guru dan buku wajib. Kemudian pengetahuan tersebut digunakan untuk menjawab soal-soal yang bersifat mengulang dan mengaplikasikannya pada masalah rutin.

Pada pembelajaran dengan menggunakan teknologi informasi siswa dibantu untuk lebih memahami pengetahuan berupa fakta, konsep dan prosedur yang disajikan dalam bahan ajar, karena bahan ajar yang dibuat berbasis komputer menjadikan bahan ajar menjadi lebih informatif dan komunikatif.

Bahan ajar elektronik yang interaktif memberikan keleluasaan bagi siswa untuk mengulang kembali serta mempelajarinya kapan saja dan di mana saja mereka berada tanpa 
harus bimbingan dari guru, karena dengan bahan ajar yang interaktif dapat menggantikan peran guru dalam memahami materi yang disajikan pada bahan ajar tersebut. Dengan demikian dapat dikemukakan bahwa dalam pembelajaran menggunakan bantuan komputer untuk memperoleh pengetahuan dan keterampilan lebih mudah diperoleh dan dipelajari ulang sehingga siswa lebih mudah menyelesaikan masalah yang disajikan. Lebih dari itu teknologi informasi pun dapat menampilkan visualisasi dari materi ajar yang diberikan secara cepat dan akurat. Visualisasi yang ditampilkan secara menarik, dapat digerakkan dan diubah bentuk serta ukurannya, memberi kesempatan kepada siswa untuk melakukan eksplorasi dan observasi dengan mudah. Eksplorasi sangat diperlukan ketika siswa berusaha memahami suatu konsep untuk membangun pengetahuannya.

Tidak seperti dalam pembelajaran biasa yang membuat siswa lebih cenderung bersikap pasif dalam menerima pembelajaran, suasana kelas dalam pembelajaran menggunakan komputer lebih bersifat dinamis. Siswa terlihat aktif berdiskusi dengan kelompoknya dalam upaya menyelesaikan masalah. Keaktifan siswa tersebut terjadi karena dalam pembelajaran tersebut tidak saja menekankan pada penguasaan materi tetapi juga keterampilan yang diperlukan dalam menyelesaikan masalah, pemerolehan pengetahuan dan bekerja sama. Hal ini merupakan salah satu karakteristik pembelajaran berbasis teknologi informasi yang berpusat pada siswa, karena dalam pembelajaran berbasis teknologi informasi siswa dituntut berusaha dengan sungguh-sungguh mempelajari bahan ajar yang disajikan, mengidentifikasi apa yang dipelajari, mencari penyelesaian masalah dan bagaimana cara terbaik untuk menyelesaikan masalah. Siswa perlu mengetahui bagaimana mengidentifikasi informasi yang penting yang perlu mereka dipelajari, mencari dan memperoleh informasi, serta bagaimana menggunakan informasi tersebut untuk menyelesaikan masalah.

Belajar mengunakan bahan ajar elektronik interaktif yang terintegrasi nilai-nilai keislaman memungkinkan siswa untuk menyelesaikan masalah yang berhubungan dengan masalah nilai-nilai keislaman seperti zakat, ayat dalam Al-Qur'an, ifaq dan shodaqoh, lebih banyak daripada yang dikerjakan pada kelas pembelajaran biasa. Selain itu interaksi dalam memecahkan masalah lebih mendekati kenyataan tentang bagaimana siswa menyelesaikan masalah dalam kehidupan sehari-hari yang berhubungan dengan nilai keislaman. Hal ini sangat diperlukan ketika siswa berada di luar lingkungan sekolah seperti di lingkungan masyarakat dan lingkungan tempat bekerja nantinya.

Kemampuan berpikir matematis yang diukur dalam penelitian ini adalah kemampuan koneksi matematis.Berdasarkan temuan penelitian, dapat disimpulkan bahwa terdapat peningkatan yang signifikan pada kemampuan koneksi matematis siswayang mendapat pembelajaran menggunakan bahan ajar elektronik interaktif yang terintegrasi nilai-nilai keislaman. Peningkatan tersebut disebabkan oleh aktivitas siswa dalam proses menyelesaikan masalah. Selain itu penggunaan teknologi komputer dapat lebih memudahkan siswa bereksplorasi untuk menentukan pola, membuat kesimpulan dan berkomunikasi intensif dengan sesama peserta belajar lain. Hal ini sesuai dengan temuan Stoney dan Oliver (1999), mereka menyimpulkan bahwa teknologi komputer dapat melibatkan siswa secara mental dan mengkondisikan siswa untuk berpikir ketingkat yang lebih tinggi.

Pada siswa yang mengalami pembelajaran menggunakan bahan ajar elektronik interaktif yang terintegrasi nilai-nilai keislaman jika ditinjau dari banyak siswa yang 
mendapat skor tes akhir kemampuan koneksi melebihi nilai Kriteria Ketuntasan Minimal (KKM) yang ditentukan sebesar 78 maka dapat disimpulkan $81 \%$ siswa berhasil melebihi nilai KKM mata pelajaran matematika yang telah ditentukan. Fenomena ini menunjukkan bahwa pembelajaran menggunakan bahan ajar elektronik interaktif yang terintegrasi nilai-nilai keislaman sangat cocok digunakan untuk peningkatan kemampuan koneksi matematis. Hal ini sesuai dengan temuan Koohang dan Durante (2003) yang menyimpulkan bahwa siswa yang belajar dilingkungan berbantuan komputer akan meningkatkan motivasi yang tinggi untuk memajukan diri sendiri, memiliki kedisiplinan mandiri yang tinggi, dan manajemen waktu yang baik dalam belajar sehingga hasil belajar yang didapat meningkat secara signifikan.

Peningkatan kemampuan koneksi matematis siswa ditunjukkan dengan kemampuan siswa memahami koneksi antar keterampilan matematis dan koneksi matematis dengan mata pelajaran lain. Sebagai ilustrasi, untuk menjawab pertanyaan tentang table distribusi frekuensi dan sebaran warga yang membayar zakat, infak dan sodaqoh, yang harus dipahami siswa adalah dapat mengaitkan persoalan ini pada mata pelajaran agama. Siswa harus paham terlebih dahulu bagaimana dan apa syarat-syarat seseorang berkewajiban membayar zakar, infat maupun sodaqoh, baru setelah itu siswa dapat menjawab bagaimana table distribusi frekuensi dan data sebarannya. Di sini kemampuan koneksi matematis siswa digunakan, siswa diharapkan mampu membuat koneksi antara pelajaran matematika dengan mata pelajaran agama.

\section{SIMPULAN DAN SARAN}

Berdasarkan analisis data dan pembahasan yang telah dipaparkan pada bab sebelumnya, diperoleh beberapa kesimpulan sebagai berikut:

1. Pembelajaran dengan menggunakan bahan ajar elektronik interaktif yang terintegrasi nilai-nilai keislaman pada proses pembelajaran terbukti secara signifikan dapat meningkatkan kemampuan koneksi matematis siswa, selaian itu pengintegrasian nilai keislaman menambah pengetahuan siswa tentang praktek ibadah yang benar.

2. Peningkatan kemampuan koneksi matematis siswa yang mendapat pembelajaran dengan menggunakan bahan ajar elektronik interaktif yang terintegrasi nilai-nilai keislaman berada pada kategori sedang. Hal ini menunjukkan bahwa siswa telah mengalami peningkatan kemampuan koneksi matematis lebih baik dibandingkan hasil sebelumnya.

\section{DAFTAR PUSTAKA}

Borg \& gall (1983), Educational research: An troduction Longman Edisi2 PenerbitMcKay University of Wisconsin - Madison.

Businskas, A. (2005). Making Mathematical Connections In The Teaching Of School Mathematics. Proceedings of the $27^{\text {th }}$ annual meeting of the North American Chapter of the International Group for the Psychology of Mathematics Education.

Conway P. F. (2006). Laptops Initiative for Students with Dyslexia or other reading and writing difficulties: Early Implementation Evaluation Report. Dublin: National Centre for Technology Education (NCTE). 
Fisher, R. (1995). Teaching Children to Think. Hong Kong: Stanley Thornes Ltd.

Geller L.R., Chard D.J. Fien H. (2008). Making Connections in Mathematics: Conceptual Mathematics Intervention for Low-Performing Students. Remedial and Special Education. Volume 29 Number 1.

Henningsen, M. dan Stein, M. K. (1997). Mathematical Task and Student Cognition: Classroom Based faktors That Support and Inhibit High Level Thinking and Reasoning. Journal for Research in Mathematics Education. 28(1), 91-99.

Koohang, A. dan Durante, A. (2003). "Learners Perception toward the Web-Based Distance Learning Activities/Assignments Portion of an Undergraduate Hybrid Instructional Model". Journal of Information Technology Education [Online], 2(2), 105-113.

Liwa Irrubai, (2004).Integrasi nilai-nilai kesilaman dalam pengajaran ilmu sosial dasar. Tesis, PPS UPI Bandung

Meltzer, D.E. (2002). The Relationship Between Mathematics Preparation and Conseptuan Learning Gain in Physics: A Possible Hidden Variable in Diagnostic Pretest Scores. American Journal Physics. 70(2), 1259-1267

Mousley, J. (2004). An Aspect Of Mathematical Understanding: The Notion Of Connected Knowing. Proceedings of the 28th Conference of the International Group for the Psychology of Mathematics Education. Vol 3 pp 377-384

Mullis, I.V.S. et al. (2000). TIMSS 1999: International Mathematics Report. Boston: ISC.

NCTM. (2000). Principles and Standards for School Mathematics, Reston, Virginia.

Nuryadin, Nurdin (2004:59). Pengembangan Multimedia Pembeljaran Matematika Interaktif Pada Pokok Bahasan Persegi Dan Persegi Panjang dalam Upaya Menumbuhkembangkan Kompetensi Siswa SLTP. Tesis, PPS UPI Bandung

Peterson, P.J. (1988). Teaching for Higher-Order Thinking in Mathematics: The Challenge for the Next Decade. Dalam D.A. Grouws, T.J. Cooney, \& D. Jones (Eds.), Effective Mathematics Teaching. Virginia: NCTM

Riedesel, C.A., Schwartz, J.E., dan Clements, D.H. (1996). Teaching Elementary School Mathematics. Boston: Allyn and Bacon.

Ruseffendi, E.T. (1994). Dasar-dasar Penelitian Pendidikan dan Bidang Non Eksakta Lainnya. Semarang : IKIP Semarang Press.

Suherman. (2003). Evaluasi Pembelajaaran Matematika. UPI Bandung : JICA.E.T.

Suherman, E., \& Kusumah, Y.S. (1990). Petunjuk Praktis untuk Melaksanakan Evaluasi Pendidikan Matematika. Bandung : Wijaya Kusumah.

Sudjana, Metoda Statistika, Tarsito, Bandung, Cet. 3, hal. 239

Sumarmo, U. (1987). Kemampuan Pemahaman dan Penalaran Matematika Siswa SMA Dikaitkan dengan Kemampuan Penalaran Logik Siswa dan Beberapa Unsur Proses Belajar Mengajar. Disertasi pada Sekolah Pasca Sarjana UPI.: Tidak Diterbitkan

Sutiarso, S. (2000). Problem Posing, Strategi Efektif Meningkatkan Aktivitas Siswa dalam Pembelajaran Matematika. Makalah pada seminar di Bandung: Tidak diterbitkan.

Stoney, S. \& Oliver, R. (1999). "Exploring the Nature of Self-Regulated Learning with Multimedia". The Journal of Computer-Enhanced Learning [on-line at:] http://imej.wfu.edu/

Walmsley, H. (2003). International Bright Young Things. Internet Magazine, March, pp.44, 45. 